\title{
Structure, Conduct, and Performance (SCP) of Fruit Marketing in Ethiopia
}

\author{
Yimer Ayalew Ahmed \\ School of Management, Wollo University, PO box 1145, Dessie, Ethiopia
}

\begin{abstract}
This article has analyzed the structure, conduct and performance (SCP) of fruits marketing in Ethiopia. The specific objectives of the study were to identify the major fruit marketing channels and evaluate the market margins for key fruit marketing channels in the study area. A multi-stage sampling technique was used to select sample fruit farmers. The data were collected by semi structured questionnaires, and rapid market appraisal. Results from the descriptive analysis shows that local collectors and retailers are the most important buyers of fruit from producers. The market actors in the survey period were producers, rural assemblers, retailers, wholesalers and consumers. Fruit production was constrained by lack of market to absorb the production; large number of middlemen in the marketing system, absence (weakness) of marketing institutions safeguarding farmers' interest and rights over their marketable produces (e.g. cooperatives); lack of coordination among producers to increase their bargaining power. The contribution of this study provides additional evidence to the existing body of knowledge in marketing research by researching the significance of SCP in the fruit marketing chain analysis in Ethiopia. Besides, this investigation adds to the literature to better understand why some marketing chain succeeds and others fail, and it underpins the structure, conduct and performance model to be context specific.
\end{abstract}

Keywords: Marketing System, Structure, Conduct and Performance, fruit, Ethiopia

DOI: $10.7176 / \mathrm{JMCR} / 68-01$

Publication date:May $31^{\text {st }} 2020$

\section{Introduction}

Agricultural marketing is the most significant energetic force of economic development and contains a guiding and simulating impact on production and distribution of agricultural products. The agricultural marketing system needs to change the welfare of agrarian societies (Dessalegn, Jayne, \& Shaffer, 1998). As indicated by FAO (2007) in developing nations, most permanent crops produced by smallholder agriculturists and their product were marketed by the non-public entrepreneurs who works as marketing chain, and distribute the products to terminal markets. In spite of the fact that the marketing chain is notable, smallholder ranchers particularly confront staggering expense in accessing markets, inadequate and uncoordinated crop market information systems.

As indicated by Amha(1994) in Ethiopia the performance of agricultural marketing system is constrained by several factors, for example, poor quality of agricultural produce, absence of market facilities, weak extension services that ignored marketing development, poor linkage of research and extension service, lack of marketing information and intelligent services, excessive value and provide fluctuations, restricted access to credit, and transportation problems. Notwithstanding these the main constraints to increasing the welfare of smallholders is their inability to access markets (Abebe, 2009). He additionally proposed that, reduces incentives to participate in economic transactions and results in subsistence instead of market-oriented production systems.

Farmers in Ethiopia especially in the Amhara region are more focused on the production part without having adequate market information about their products, and the level of development of the marketing system in Amhara region is quite low. There are a number of constraints in all aspects of the agricultural marketing system in the region. The following are the agricultural marketing problems identified by Demelash(2003) with a wider perspective and yet very relevant to the region; Weak bargaining power and poor marketing skills, Low level of marketable surplus, Inadequate market information system, Infrastructure problem, Fertilizer and Seed marketing. As per Colman (1999) due to different marketing constraints the small holder farmers are not getting the right share of consumer price and they are not producing and selling their produce in an organized manner so that some of their benefit may transfer to the middlemen. Therefore, the objectives of the study were to identify the major fruit marketing channels; and evaluate the market margins for key fruit marketing channels in the study area.

\section{Literature Review}

The structure, conduct and performance (SCP) paradigm is a tool used to analyze markets in order to establish the relationship between market structure, market conduct and the market performance (Tirole, 1988). The paradigm is based on two theories; industrial organization and price theory. The industrial organization theory proposes the use of degree of vertical integration, and government participation in examining how a particular firm behaves. The structure of the market, which refers to how the market is functioning, is the concept behind the industrial organization theory. According to Ramsey (2001), it is best to describe how the firm operates in terms of the type of market it operates in rather than only focusing on the firm itself and its internal components. The price theory, 
on the other hand, is concerned with explaining the economic activities that create and/or transfer value in the trade of goods and services between different economic actors (Weber, 2012). The (S-C-P) model is an analytical approach used to study how the structure of the market and the behavior of sellers and buyers of different commodities and services affect the performance of market (Scarborough and kydd, 1992; Pomeroy and Trinidad, 1995; Mendoza, 1995; Funke, Raphel, \& Kabir, 2012).

\subsection{Market structure}

Market structure is the atmosphere in which the firm operates. It comprises; the degree of market transparency which refers to the availability of relevant market information, its distribution among buyers and sellers, and its adequacy in terms of price sharpening(Clodius and Mueller, 1961, cited in Zeberga,2010;Mendoza, 1995)and also Funke, Raphel, \& Kabir(2012)market structure consist features of the market that influence the rivalry among the buyers and sellers operating in a market, which the condition of entry to the market referring to the relative ease or difficulty with which seller may enter the market. This is for the most part dictated by the favorable circumstances that set up sellers have over potential entrants' barriers to entry into the market and the nature of trading relations among market participants(Scarborough and kydd,1992).

\subsection{Market conduct}

Market conduct refers to the patterns of behavior that dealers and other market members accept to influence or conform to the market in which they offer or purchase. These consists price setting behavior, and buying and selling practices (Funke, Raphel, \& Kabir, 2012). As per Dessalegn, et al., (1998) during the analysis of pricing behavior, the following things were seriously considered: the main determinants of price, value setting instruments, factors that influence the setting of price, the basis for price differentiation and the impact of physical location of the market on prices and marketing arrangements.

\subsection{Market Performance}

Market performance refers to the degree to which markets result in outcomes that are esteemed good or favored by society (Funke, Raphel, \& Kabir, 2012).It infers how well the market satisfies certain social and private objectives. These incorporate, price levels and price stability in the long and short term, profit levels, efficiency and quantities and quality of commodities sold. It indicates how successfully the firm's aims are accomplished, which demonstrates how well the process of marketing is carried out (Pomeroy and Trinidad, 1995). Market performance can be evaluated by analysis of margins of marketing agents in different channels. To assess the market margins is relevant to achieve the objective marketing system (Sajjad,et al.,2008). Marketing margins are often estimated for different levels like wholesale, retail etc. in the marketing system (Fateh, 2009). Marketing margin looking in to different way, a gross marketing margin for a particular commodity is the difference between what the consumer pays for final product and the amount the producer receives and also marketing margins are the differences between prices at two market levels. Generally, Fateh (2009) explain that Marketing margins are being examined on the basis of data obtained on prices at different stages of the marketing chain.

\section{Materials and Methods}

This research relies on quantitative and qualitative types of research approach. Furthermore, the researchers have used a descriptive and cross-sectional research design.

A multi-stage sampling technique was used to select sample fruit farmers. First, using purposive sampling technique, three Kebeles were selected from the woreda. The identification of kebeles was made through secondary data based on production coverage of the fruit. From these purposively selected kebeles the researchers selected 250 sample sizes using the slovin's sample size formula. In the second stage, using the population list of fruit growing farmers from the sampled Kebeles, the intended sample size were selected using proportional stratified sampling technique. Finally based on the sampling frame from each kebele, Random Sampling technique was used to select the sample fruit producing farmers.

In addition, market related data were collected from 7 assemblers and 9 wholesalers and 34 retailers. The data were collected by semi structured questionnaires, rapid market appraisal, semi structured interview and observation. Besides, the researcher applied descriptive data analysis with statistical tools with the help of software package such as SPSS.

In addition to this, in the study marginal analysis is used to address the objective of market margin of each actor in the market channels. Sajjad,et al.(2008) evaluate the marketing margin using the formulas listed below, Therefore, for the purpose this study these formula was used by considering the average sales prices of different participants in the fruit market channel (farmers, local collectors, retailers and wholesalers) to evaluate the market margin. 


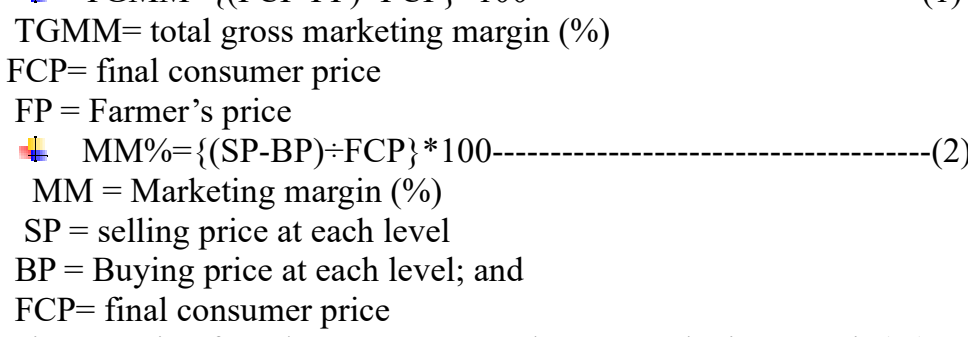

\section{Analysis and discussion of results}

\subsection{Fruit Marketing Chain Actors and Their Role}

Fruits in Habru Woreda passes through different channels before it reach the end users. The major actors in fruit marketing channel were producers, local assemblers, wholesalers and retailers. The characteristics and roles played by each market actor are described in following manner below:

\section{Producers}

Producers are the sole source of fruit products that are corner stone in the development of the marketing chain. They have various market outlets to inject their product into the marketing chains at the alternative periphery of the supply chain. They are the starting point in the chain. They are the first link actors who produce and supply fruit products to the market. In the study area fruit producers sell their products to local collectors, retailers, wholesalers or directly to consumers in the area.

Table 1 presented below show that farmers totally supplied 2456 quintals of orange product. From this total orange production supplied by farmers $39 \%$ of it supplied to local assemblers, $31 \%$ to retailers, $14 \%$ and $16 \%$ of it were supplied to consumers and wholesalers respectively.

Generally, the above analysis indicated that the majority of orange producers supplied their fruit to local collectors, while all farmers supplied small amount of orange, products to the consumers directly.

Table 1: Quantity of fruit supplied to different market actors by Producers

\begin{tabular}{|l|c|l|}
\hline Description & Quantity supplied in Quintal & percent \\
\hline & (Orange) & $\%$ \\
\hline To local assemblers & 953 & 39 \\
\hline To retailers & 768 & 31 \\
\hline To consumers & 347 & 14 \\
\hline To Wholesalers & 388 & 16 \\
\hline Total & 2456 & 100 \\
\hline
\end{tabular}

Source: Survey Result

\section{Rural Assemblers (Local Collectors)}

They are farmers who collect fruits from farmers in village markets for the purpose of reselling it to wholesalers, retailers and consumers. Farmer traders or rural assemblers are actors who play great role in coordinating the transactions between and within producers and other traders and also they do know areas of surplus well. Though rural assembler found in the study area were limited in number. Even though, in the study area, number of local assemblers in fruit market is not as such large, they purchase the products from producers and sell to retailers, Wholesalers and the consumers. The assemblers purchased totally 953 quintals of orange, from farmers and about $49.8 \%$ of orange, were sold to retailers. About $42 \%$, of orange, purchased by assemblers were sold to directly to consumers. Additionally, $8.2 \%$ of orange products that purchased by assemblers were sold to wholesalers (Table, 2).

Table 2: Quantity of sales to different market actors by assemblers

\begin{tabular}{|l|c|c|}
\hline Description & Quantity sold in quintals & percent \\
\hline & Orange & \\
\hline To retailers & 475 & 49.8 \\
\hline To consumers & 400 & 42 \\
\hline To Wholesalers & 78 & 8.2 \\
\hline Total & 953 & 100 \\
\hline
\end{tabular}

Source: Survey result

\section{Wholesalers}

They are actors in the fruit marketing chain who purchase orange and banana directly from farmer and local collectors from woreda markets and sold to the retailers and terminal markets (Dessie). These traders have strong 
financial resource and better information on the price and supply of fruit in the source and destination markets. In fruit marketing chain whole sellers are conducting important marketing functions by linking the woreda and other markets area with the terminal market. According to the survey result presented in table 3, they supplied 188 quintals of orange products to retailers and 278 quintals supplied to terminal market.

Table 3: Quantity of fruit supplied to different market actors by fruit Wholesalers

\begin{tabular}{|l|c|l|}
\hline Description & Amount sold in quintals & $\%$ of sales \\
\hline & Orange & $\%$ \\
\hline To retailers & 188 & 41 \\
\hline To consumers & - & \\
\hline To terminal market & 278 & 59 \\
\hline Total & 466 & 100 \\
\hline
\end{tabular}

Source: Survey result

\section{Retailers}

Retailers in fruit marketing chain are those actors who perform the last marketing function by linking consumers with other traders and/or producers. These are the ultimate actors in the market chain that purchase and deliver fruits product to consumers. According to the survey result and RMA in the study area retailers are the major actors in fruit marketing chain. This indicates that all actors who participate in fruit marketing chain supplied their product to retailers.

\section{Consumers}

Consumers for this particular study mean those households who bought and consumed orange. They are individual households they bought the commodity for their own consumption only.

\subsection{Market structure}

In this study the market structure of orange, assessed in the form of market transparency and condition of entry into and exit from trade were used as evaluation criteria.

\section{Degree of market transparency}

The degree of market transparency refers to the relevance and consistency of market information between the participants for their marketing choice. In a transparent market participant have adequate information about their competitors regarding their source of supply and buying prices for better decisions. According to the informal survey, market information is not transparent among traders and producers and there is no well-established system of dissemination market information in woreda. But, in the study area all traders use market information regarding to their marketing activities like price of the market, demand and market place.

Based on trader's survey result in table 4 indicates, about $32 \%$ of the sample traders get market information through personal observation, $40 \%$ from other traders and $28 \%$ through the combination Personal observation and other traders. This implies that there is a relationship between traders to traders because the majority of the respondents get market information from other traders.

Table 4: Source of market information for traders

\begin{tabular}{|c|l|l|l|l|}
\hline $\begin{array}{l}\text { Source of market } \\
\text { information }\end{array}$ & $\begin{array}{l}\text { Personal } \\
\text { observation }\end{array}$ & Traders & $\begin{array}{l}\text { Personal observation, and other } \\
\text { traders }\end{array}$ & Total \\
\hline Frequency & 16 & 20 & 14 & 50 \\
\hline$\%$ & 32 & 40 & 28 & 100 \\
\hline
\end{tabular}

Source: Survey result

2. Barrier to entry and exit

According to the interview made with trade and industry officers there is no restriction to enter in the fruit markets with respect to license. As a rule, a trader who has license in one business is not allowed to perform any other businesses other than the business for which he/she is licensed. But in the study area according to the rapid appraisal and survey result almost all of the retailers and rural assemblers had no license. The assessment implies that absence of trading license for fruit trading activities not restrict traders to enter and exit in fruit trading businesses.

The regulatory action to control unlicensed traders was minimal in the study area. Since these unlicensed traders do not pay tax, they have the opportunity to charge competitive price and discourage the licensed traders. Traders that have licensed do not blame about payment for licensing and renewal. But, they claim that the tax rate is unfair, high and very subjective. The survey result indicated that traders pay tax based on the volume of the product handled but there was no continuous and proper counting.

The other point regarded as barrier to entry is education level of traders. As indicated in sample, all traders had received elementary and secondary education. This indicates that the level of formal education seem to be a barrier to entry, because all fruit traders had formal education. Besides, important thing for almost all traders strictly underlined the importance of experience as entry barrier. Because experience provide a skill to manage 
customers, lobbying selling and buying customers, cheating protect anybody to enter the business to traders.

\subsection{Fruit Market conduct}

In this study conduct of the fruit market is analyzed in terms of the availability of price information, price setting, purchasing and selling strategies of producers and traders.

\section{Conduct of producers}

According to the survey result, all producers supply the product to the market. However, $44 \%$ the sample farmers have market information before sale and their sources of information are other fruit sellers and personal observation.

Farmers reported that their selling strategy is unstructured to any buyers. There was no any contract-based marketing and also they were not organized in terms of cooperative. Starting from production up to marketing every farmer produces and sells on individual basis. This affects their bargaining power during the sale of fruit. Respondents were asked in rapid market appraisal what issues they took into account to decide for whom to sell. They responded as they offered to anybody as far as he/she offered better price. In table 5, the survey data indicated that the price setting strategy the producers use to sale the product is $25.2 \%$ through negotiation, $25.2 \%$ by the current market demand and supply, $40 \%$ by buyers (traders) and the remaining $9.6 \%$ of respondents replied that they set the price by themselves. This shown that the majority of producers did not acquire any power in price decision. Hence, they all are found to be price takers.

Table 5: price setting strategy of producers to market the product

\begin{tabular}{|l|c|c|}
\hline Who sets selling price in a market? & Frequency & Percent \\
\hline Producers( myself) & 24 & 9.6 \\
\hline Buyers(traders) & 100 & 40 \\
\hline Set by demand and supply & 63 & 25.2 \\
\hline Negotiations & 63 & 25.2 \\
\hline Total & 250 & 100 \\
\hline
\end{tabular}

Source: Survey Result

\section{Traders market conduct}

According to survey result, the traders have purchased fruit products using family members and through brokers, about $57 \%$ of the traders purchased directly without brokers( himself and their family members ), $24 \%$ of them purchased through brokers, and the rest of traders bought by combination of direct purchase and brokers. In addition, the survey result shown in table 6 shows, $28 \%$ of the traders use the service of brokers at the time of sale, $61 \%$ of them sale personally and with their family members and the residual $11 \%$ of them sale through the combination of their family members, trader himself and brokers. According to RMA and survey result, brokers are very important for wholesalers and assemblers at the time of purchase and sell because they enable to save time, make selling and buying easily by contacting buyer and seller and they enable reduce the exchange price.

Price setting is crucial in fruit trading activity. According to the survey results presented in table 6 , about $34 \%$ of the respondents set the price by negotiation between the sellers and purchasers, about $32 \%$ of traders reported as they set price by the market demand and supply, and remaining $16 \%$ and $18 \%$ of traders reported price is set by sellers and buyer themselves respectively. But in RMA and observation in all cases prices of fruit have been decided by traders, hence traders were price makers.

The data in table 6 shows that fruit traders have used different methods to attract their suppliers. Thus, out of total traders $20 \%, 28 \%$ and $32 \%$ of traders attracted their suppliers by paying better price, by visiting them and by fair scaling respectively. While, $12 \%$ and $8 \%$ traders reported that offering credit service and giving pre-payment are used by traders to attract their suppliers. 
Table 6: Price setting and method of attracting

\begin{tabular}{|c|c|c|}
\hline Price setting strategy & $\begin{array}{l}\text { Frequency } \\
(\mathrm{N}=50)\end{array}$ & Percent \\
\hline Negotiation & 17 & 34 \\
\hline Set by demand and suppliers & 16 & 32 \\
\hline My self & 9 & 18 \\
\hline Sellers & 8 & 16 \\
\hline \multicolumn{3}{|c|}{ Method of attracting suppliers } \\
\hline Giving better price & 10 & 20 \\
\hline By visiting them & 14 & 28 \\
\hline Fair scaling & 16 & 32 \\
\hline Offering credit service & 6 & 12 \\
\hline Giving pre-payment & 4 & 8 \\
\hline
\end{tabular}

\subsection{Fruit market performance}

The fruit market performance was evaluated based on the level of marketing margins.

\section{Marketing margin}

As cited by Sajjad,et al.(2008) evaluate the marketing margin by using the formulas listed in methodology, Therefore, for the this study these formula was used by considering the average sales prices of different participants in the fruit market channel (farmers, local collectors, retailers and wholesalers) to evaluate the market margin.

Table 7: Player group's marketing margin as a proportion of final consumer price (Birr/quintal) in orange marketing.

\begin{tabular}{|c|c|c|c|c|c|c|c|}
\hline \multirow[t]{2}{*}{ Participants' } & \multicolumn{4}{|c|}{ Orange marketing channels } & \multirow[b]{2}{*}{$\begin{array}{l}\text { Channel } \\
\mathrm{V}\end{array}$} & \multirow[b]{2}{*}{$\begin{array}{l}\text { Channel } \\
\text { VI } \\
\end{array}$} & \multirow[b]{2}{*}{$\begin{array}{l}\text { Channel } \\
\text { VII }\end{array}$} \\
\hline & $\begin{array}{l}\text { Channel } \\
\text { I }\end{array}$ & $\begin{array}{l}\text { Channel } \\
\text { II }\end{array}$ & $\begin{array}{l}\text { Channel } \\
\text { III }\end{array}$ & $\begin{array}{l}\text { Channel } \\
\text { IV }\end{array}$ & & & \\
\hline $\begin{array}{l}\text { Producers: } \\
\text { Selling price }\end{array}$ & 465 & 465 & 450 & 450 & 450 & 465 & 465 \\
\hline Farmer's share \% & 100 & 84.55 & 82.57 & 81.82 & - & 84.55 & - \\
\hline TGMM \% & & 15.45 & 17.43 & 18.18 & & 15.45 & \\
\hline $\begin{array}{l}\text { Local collector: } \\
\text { Selling price }\end{array}$ & & & 545 & 545 & 545 & & \\
\hline TGMMLC\% & & & 17.43 & 17.27 & & & \\
\hline $\begin{array}{l}\text { Wholesaler: } \\
\text { Selling price }\end{array}$ & & & & & - & 545 & - \\
\hline TGMMW\% & & & & & & 14.54 & \\
\hline $\begin{array}{l}\text { Retailer: } \\
\text { selling price }\end{array}$ & & 550 & & 550 & & 550 & \\
\hline TGMMR\% & & 15.45 & & 0.91 & & 0.91 & \\
\hline Final consumer price* & 465 & 550 & 545 & 550 & - & 550 & - \\
\hline
\end{tabular}

Note: *- Final consumer price indicated that individual households; they bought the commodity for their own consumption only.

As indicated in table 7 the farmer's share of the total consumer price was $100 \%$ in channel I. This shows that all producers share over all the entire consumers' price and traders have no shares from the total consumer price of the channel. But, producers share $84.55 \%$ in channel II, $82.57 \%$ in channel III, $81.82 \%$ in channel IV and $84.55 \%$ in channel VI. This implies that $15.45 \%$ of in channel II, $17.43 \%$ in channel III, $18.18 \%$ in channel IV and $15.45 \%$ in channel VI of the total consumer price shared by traders.

The above Table 7 also replied that the gross marketing margins of each orange trader as a proportion of final consumer price. As it is shown in channel II the retailer's market margin constituted $15.45 \%$ of the final consumer price. This implies that out of the total market participant agents in channel II the overall consumer price get by the retailers. Similarly, in channel III the assembler's market margin constituted $17.43 \%$ of the final consumer price .In channel IV the assembler's gross market margin constituted $17.27 \%$ of the final consumer price. While, the retailer's gross market margin constituted $0.91 \%$ of the final consumer price. This shows that a large proportion of the marketing margin is generated in channel IV goes to the assembler's (local collectors). In channel VI the total gross marketing margin of the wholesaler's was $14.54 \%$ of the final consumer price while, retailer's total 
gross marketing margin was $0.91 \%$ of the final consumer price.

Generally, the researcher can concludes that the total gross marketing margin (TGMM) is highest in channel IV which accounts $18.18 \%$ of the final consumers' price and among all orange trader participants local collectors get the highest gross marketing margin which accounts $17.43 \%$ of final consumers' price.

\section{Conclusion and Recommendation}

Ethiopia has a great potential for horticultural crops production. However, out of the country's total potential areas of horticultural crop production, the contribution of horticultural crops both to the diet and income in Ethiopians is insignificant. A number of factors may have affected the amount of marketable supply of fruits at farm level in the country. In the case of Habru Woreda to the major actors in orange fruit marketing channels were producers, local assemblers, wholesalers and retailers. In Orange market seven alternative channels were identified in Habru Woreda respectively. Producers---Retailers----Consumers was the most important channels in terms of total volume marketed for in orange fruits as compare to other channels in terms of volume supplied.

Total gross marketing margin in orange trading is highest in channels IV which accounts a TGMM of $18.18 \%$. Producers share in orange trading from the price paid by consumers is highest in channel I which accounts $100 \%$ of the price paid by consumers. In addition to this, in all orange traders, local collectors get the highest gross marketing margin which accounts $17.43 \%$ of the consumer price.

In the study area, market information is not transparent between traders and producers and there is no wellestablished system of dissemination of market information in the Woreda. And also in study area, majority of traders had no license and the regulatory action to control unlicensed traders was minimal. In addition to this, licensing traders they claim that the tax rate is unfair, high and very subjective.

In terms of market conduct, farmers selling strategy was unstructured to any buyers and no any contractbased marketing. They offered to anybody as far as he/she offered better price. But, most of the time producers did not acquire any power in price decision. Hence, they are found to be price takers. And also the price setting is crucial in fruit trading activity, in the study area prices of fruit have been decided by traders and hence, traders were price makers.

\section{Reference}

Abebe, A. (2009). Market chain analysis of honey production in Atsbi Wemberta District, eastern zone of Tigray national regional state (Master dissertation, Haramaya University).

Amha, W. (1994). Food grain marketing development in Ethiopia after the market reform 1990: a case study of Alaba Siraro District. Berlin (Germany), Verlag Koster, 1994.

Colman, Y. (1999). Improving the Legal Environment for Agricultural Marketing. Agricultural Service Bulletin.

Demelash, S.(2003). A review on Agricultural Marketing Problems and Possible Solutions in Amhara Region. Bahir Dar, Ethiopia.

Department of Agriculture.(2002).Annual Report on Socio-Economic Information of North Wollo Zone (unpublished).' Woldya.

Dessalegn, G., Jayne, T. S., \& Shaffer, J. D. (1998). Market structure, conduct, and performance: Constraints of performance of Ethiopian grain markets (No. 55597). Michigan State University, Department of Agricultural, Food, and Resource Economics.

FAO (Food and Agriculture Organization).(2007). State of the World's Forests. FAO, 000, Rome.

Fateh, M. M. (2009). Structure and efficiency analysis of vegetable production and marketing in Sindh, Pakistan. Unpublished PhD Thesis in the Department of Agricultural Economics, Sindh Agriculture University, Tando Jam.

Funke, O., Raphel, B., \& Kabir, S. (2012). Market structure, conduct and performance of gari processing industry in South Western Nigeria. European Journal of Business and Management, 4(2), 99-113.

Mendoza, G. (1995). A primer on marketing channels and margins. In: Scott GJ (ed), Prices, products and people: Analyzing agricultural markets in developing countries. Lynne Reinner Publishers, Boulder, London, UK, 257-276.

Pomeroy, R. S., \& Trinidad, A. C. (1995). Industrial organization and market Analysis: Fish marketing. Prices, products and people: Analyzing Agricultural Markets in Developing Countries.

Ramsey, J. (2001). The Resource Based Perspective, Rents, and Purchasing's Contribution to Sustainable Competitive Advantage. Journal of Supply Chain Management, 37(3):38-47.

Sajjad, M., Munir, K., Dilawar, K., Mulk, S., \& Nazir, M. (2008). An Investigation into Marketing Channels and Margins of Rice in District Malakand. Sarhad Journal of Agriculture, 24(3), 479-484.

Scarborough, V., \& Kydd, J. (1992). Economic analysis of agricultural markets: A manual(Vol. 5). Natural Resources Institute.

Tirole, J. (1988). The theory of Industrial Organization. The MIT Press, London.England

Zeberga, A. (2010). Analysis of poultry market chain: The case of Dale and Alaba 'Special'Woredas of SNNPRS, Ethiopia (master dissertation, Haramaya University). 